\title{
Decay of Impurity Clusters of Nickel and Cobalt Atoms in Silicon under the Influence of Pressure
}

\author{
N.A. Turgunov*, E.Kh. Berkinov, D.Kh. Mamajonova \\ Research Institute of Physics of Semiconductors and Microelectronics at the National University of Uzbekistan, \\ 20, Yangi Almazar St., 100057 Tashkent, Republic of Uzbekistan
}

(Received 10 June 2021; revised manuscript received 20 October 2021; published online 25 October 2021)

The effect of all-round hydrostatic pressure (ARHP) on the electrophysical properties of silicon single crystals doped with nickel and cobalt has been studied. After high-temperature diffusion doping in the bulk of $n$-Si $<\mathrm{Ni}>$ and $n$-Si $<\mathrm{Co}>$ samples, accumulations of impurity nickel and cobalt atoms were found. Micrographs of impurity accumulations were obtained by the method of electron probe microanalysis and their structural forms were determined. Depending on their size and shape, these impurity clusters have a single-layer or multilayer structure. Under the influence of ARHP, no significant changes are observed in the value of the resistivity of the initial samples. In contrast to them, in silicon samples doped with nickel or cobalt, under the influence of pressure, the resistivity increases significantly. It was revealed that under the influence of ARHP in the range $P=10^{8}-1.6 \cdot 10^{9} \mathrm{~Pa}$, impurity accumulations of nickel and cobalt in silicon decompose, which leads to an increase in the resistivity of the samples by several times. Comparative analyzes of the morphological parameters of impurity accumulations before and after exposure to ARHP revealed that the process of decay of these clusters occurs in a certain sequence and depends on their size and shape. In $n$-Si $<\mathrm{Ni}>$ samples, initially, under the influence of ARHP at $P=6 \cdot 10^{8} \mathrm{~Pa}$, the disintegration of impurity clusters up to $1 \mu \mathrm{m}$ in size, having needle-like and disc-like shapes, was observed. And in samples of $n$-Si $<\mathrm{Co}>$ under the influence of ARHP at $P=4 \cdot 10^{8} \mathrm{~Pa}$, disintegration of needle-shaped and discshaped impurity clusters up to $0.5 \mu \mathrm{m}$ in size was observed. Then, at higher ARHP values $\left(P \geq 8 \cdot 10^{8} \mathrm{~Pa}\right)$, decomposition of impurity accumulations of nickel and cobalt with relatively large dimensions, which have a lenticular and spherical shape, was found.

Keywords: Pressure, Silicon, Nickel, Cobalt, Resistivity, Decay of clusters.

DOI: 10.21272/jnep.13(5).05006

PACS number: $61.72 .-\mathrm{y}$

\section{INTRODUCTION}

The study of the nature of clusters of impurity atoms formed in the bulk of semiconductor single crystals, as well as the effect of various external influences on them, allows to purposefully control the electrophysical properties of semiconductor materials. As it is known, external pressure significantly affects the electrophysical parameters of semiconductor materials and devices based on them [1-4]. In order to develop technologies for obtaining semiconductor materials with high sensitivity to external pressure, it is necessary to thoroughly study the laws of physical phenomena occurring in the bulk of a semiconductor under various conditions of its manufacture. One of the important stages of this process is semiconductor doping. In the case of diffusion doping of silicon single crystals with impurities of $3 d$ elements, only a small part of the introduced atoms is located in the crystal structure in an electrically active state [5-7]. Most of the impurity atoms are in an electrically neutral state in the form of various impurity clusters. Depending on the thermodynamic state and morphological parameters, these clusters can significantly affect the surrounding crystal structure, which leads to a change in the mechanical, electrophysical, and other properties of silicon. At the same time, it seems possible to purposefully manage these accumulations with the help of external influences $[8,9]$

Analysis of the results of studies of the influence of external factors on the properties of semiconductor materials shows that silicon single crystals with deep- level impurities have high sensitivity to external pressure $[10,11]$. When studying the transformation of the recombination properties of plastically deformed silicon, with an iron impurity introduced by diffusion doping at $1000{ }^{\circ} \mathrm{C}$, using scanning electron microscopy and nonstationary spectroscopy of deep levels, an increase in the recombination activity of dislocations was found due to the accelerated formation of iron precipitates on these defects [12].

\section{DESCRIPTION OF THE OBJECT AND RESEARCH METHODS}

Samples of $n$-Si $<\mathrm{Ni}>$ and $n$ - $\mathrm{Si}<\mathrm{Co}>$ obtained on the basis of the starting material, monocrystalline silicon of the KEF brand, grown by the Czochralski method, were selected as the object of research. Diffusion of nickel in silicon with an initial specific resistance $\rho=5 \Omega \cdot \mathrm{cm}$ was carried out at a temperature of $1523 \mathrm{~K}$ for $2 \mathrm{~h}$. Samples of $n$-Si $<\mathrm{Co}>$ were obtained on the basis of silicon with an initial resistivity $\rho=20 \Omega \cdot \mathrm{cm}$. Diffusion doping of silicon with cobalt impurity was carried out at a temperature of $1523 \mathrm{~K}$ for $4 \mathrm{~h}$. After diffusion annealing, the samples were cooled at a cooling rate $v_{\mathrm{cool}}=100 \mathrm{~K} / \mathrm{s}$.

In order to study the behavior of impurity accumulations under the influence of external pressure, the samples were subjected to all-round hydrostatic pressure (ARHP) on an LG-16 installation, in the pressure range $P=10^{8}-1.6 \cdot 10^{9} \mathrm{~Pa}$ at room temperature. Structural studies were performed by electron probe analysis using a Superprobe JXA-8800R setup.

\footnotetext{
*tna_1975@mail.ru
} 


\section{DESCRIPTION AND ANALYSIS OF RESULTS}

The results of electron probe analysis of $n-\mathrm{Si}<\mathrm{Ni}>$ samples showed that accumulations of impurity nickel atoms are formed in their volume, the image of which is shown in Fig. 1. They have various geometric shapes, and their sizes reach 4 microns. In the course of structural analyzes, the morphological parameters of impurity accumulations of nickel in silicon were determined. As it turned out, accumulations of impurity nickel atoms with sizes up to $1 \mu \mathrm{m}$ have a single-layer structure with needle-like, disc-like, lenticular and spherical shapes. Larger impurity clusters, the sizes of which exceed $1 \mu \mathrm{m}$, are mainly lenticular and spherical in shape and consist of several layers, which are separated from each other by clearly defined boundaries.

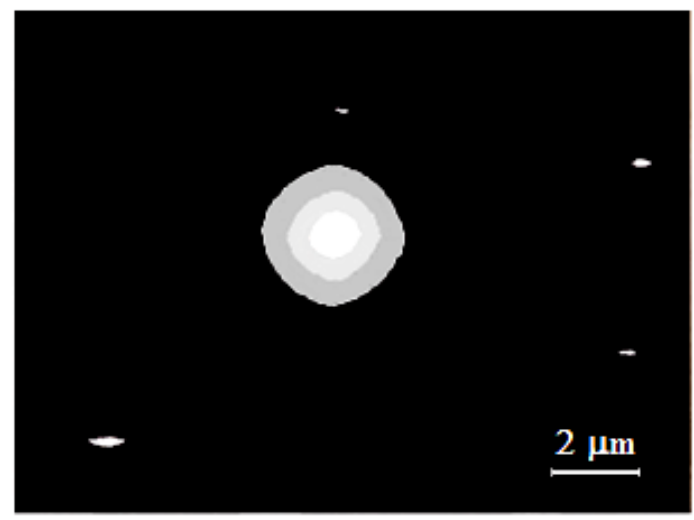

Fig. 1 - Snapshot of accumulations of impurity nickel atoms in $n$ - $\mathrm{Si}<\mathrm{Ni}>$ samples

The results of similar studies of cobalt-doped silicon samples showed that accumulations of impurity atoms with different geometric shapes and sizes are also formed in their bulk. Fig. 2 shows a snapshot of impurity clusters in $n$-Si $<\mathrm{Co}>$ samples obtained using an electron probe microscope. Relatively small clusters of impurity cobalt atoms, up to $0.5 \mu \mathrm{m}$ in size, have a single-layer structure with various geometric shapes. The resulting larger clusters, the sizes of which exceed $0.5 \mu \mathrm{m}$, have a multilayer structure.

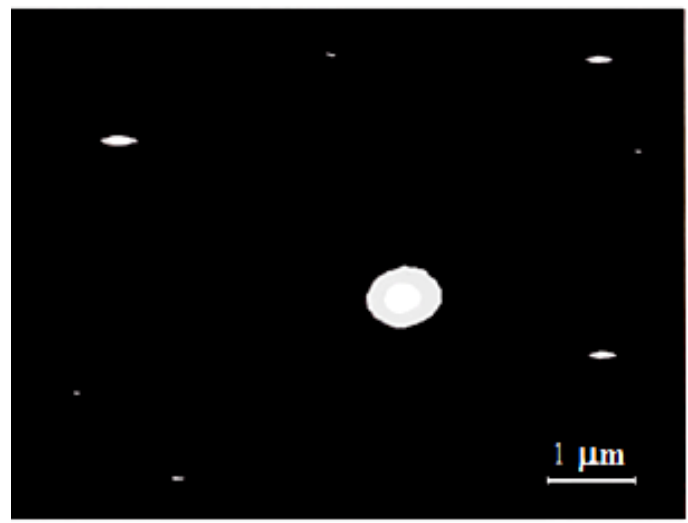

Fig. 2 - Impurity clusters of cobalt atoms in samples of $n$-Si $<\mathrm{Co}>$

Fig. 3 shows the plots of $\rho / \rho_{0}$ versus ARHP for the initial $n$-Si (curve 1, Fig. 3), as well as doped $n$-Si $<\mathrm{Ni}>$ (curve 2, Fig. 3) and $n$-Si $<\mathrm{Co}>$ (curve 3, Fig. 3) samples exposed to ARHP in the range $P=10^{8}-1.6 \cdot 10^{9} \mathrm{~Pa}$. Resistivity $(\rho)$ of each sample was measured before and after ARHP exposure. As can be seen, in the dependence of $\rho / \rho_{0}$ on the pressure of the initial samples, in the indicated pressure range, no significant changes are observed (curve 1, Fig. 3). In contrast to the initial samples, in silicon samples doped with nickel or cobalt impurities, the resistivity increases significantly under the influence of pressure.

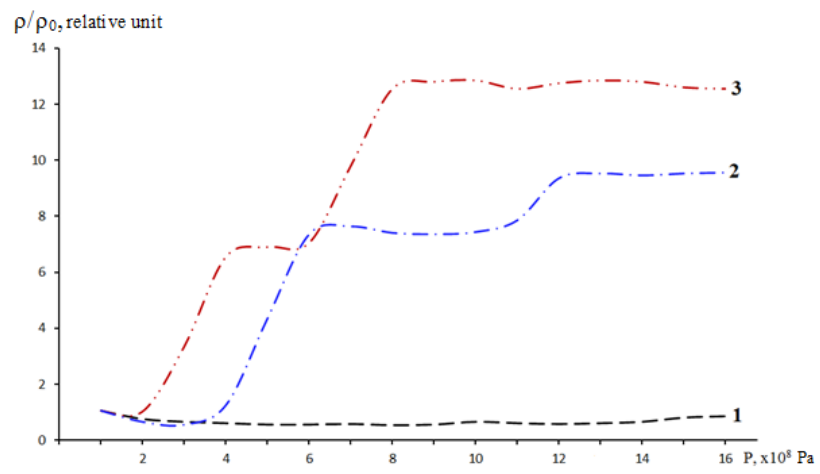

Fig. 3 - Dependence of $\rho / \rho_{0}$ on ARHP in samples: 1 - initial $n$-Si, $2-n-\mathrm{Si}<\mathrm{Ni}>, 3-n-\mathrm{Si}<\mathrm{Co}>$

Studies of the influence of ARHP on the resistivity of $n$-Si $<\mathrm{Ni}>$ samples with $\rho_{0}=0.3 \Omega \cdot \mathrm{cm}$ showed that the dependence of the value of $\rho$ on the pressure can be divided into two stages (curve 2, Fig. 3). The first of them is observed at the initial pressure values $P<4 \cdot 10^{8} \mathrm{~Pa}$, where the $\rho$ value of the samples decreases by approximately $\sim 30 \%$. With a further increase in the ARHP value $\left(P \geq 4 \cdot 10^{8} \mathrm{~Pa}\right)$, the second stage is observed, which leads to an increase in the resistivity of the samples in an abrupt manner. An increase in the pressure value in the range from $4 \cdot 10^{8}$ to $6 \cdot 10^{8} \mathrm{~Pa}$ leads to a sharp increase in the value of $\rho$ of the samples and upon reaching $P=6 \cdot 10^{8} \mathrm{~Pa}$ it increases almost 8 times. A further increase in the pressure value up to $P=10^{9} \mathrm{~Pa}$ does not lead to noticeable changes in the value of $\rho$ of the samples. At subsequent pressures $\left(P>10^{9} \mathrm{~Pa}\right)$, a sharp increase in the resistivity of the samples is again observed, and at $P=1.2 \cdot 10^{9} \mathrm{~Pa}$ it increases almost 10 times. With a further increase in the ARHP value, no significant changes in the $\rho$ value of the samples are observed.

The results of studies of the influence of ARHP on the resistivity of $n-\mathrm{Si}<\mathrm{Co}>$ samples with $\rho_{0}=7 \cdot 10^{2} \Omega \cdot \mathrm{cm}$ showed that for them this dependence also has a non-monotonic character (curve 3, Fig. 3). Initially, under the influence of pressure $P<2 \cdot 10^{8} \mathrm{~Pa}$, the value of $\rho$ of the samples decreases by $\sim 20 \%$. With an increase in the pressure value, starting from $P \geq 2 \cdot 10^{8} \mathrm{~Pa}$, a sharp increase in the value of $\rho$ of the samples is observed, and when $P=4 \cdot 10^{8} \mathrm{~Pa}$ is reached, it increases by almost 7 times. Under the influence of pressure in the range from $4 \cdot 10^{8}$ to $6 \cdot 10^{8} \mathrm{~Pa}$, the value of $\rho$ of the samples hardly changes. A further increase in the pressure value again leads to a sharp increase in $\rho$ of the samples, and upon reaching $P=8 \cdot 10^{8} \mathrm{~Pa}$, the resistivity increases up to $\sim 13$ times. A further increase in the pressure value does not lead to significant changes in the $\rho$ value of the samples. 
Such a character of the change in the value of $\rho$ in silicon samples with impurity accumulations of nickel or cobalt is explained by the fact that at initial pressure values, for $n-\mathrm{Si}<\mathrm{Ni}>$ samples up to $P=4 \cdot 10^{8} \mathrm{~Pa}$, and for $n$-Si $<\mathrm{Co}>$ samples up to $P=2 \cdot 10^{8} \mathrm{~Pa}$, due to the shift of energy levels under the influence of deformation of the crystal structure of silicon, the band gap narrows. As a result, the concentration of charge carriers increases, which leads to a decrease in the resistivity of the samples. The observed subsequent significant increases in the resistivity of the samples at certain pressures are of particular interest. Such a sharp increase in the resistivity of the samples under the given conditions of external action is mainly associated with the formation of additional centers of trapping of charge carriers in their bulk. These centers appear as a result of the disintegration of impurity clusters, which occurs under the influence of certain pressures. Subsequently, impurity atoms, which were previously in electrically neutral states in the form of clusters, pass into electrically active states.

In order to determine the reason for such changes in the values of $\rho$ of the samples, we studied the morphological parameters of impurity accumulations before and after exposure to ARHP. Comparative analyzes of the structural states of silicon samples with impurity accumulations of nickel showed that under the influence of ARHP at $P=6 \cdot 10^{8} \mathrm{~Pa}$, small (up to $1 \mu \mathrm{m}$ ) impurity accumulations of nickel with needle-like and disclike shapes decompose (Fig. 4). In addition, Fig. 4 shows that under the influence of ARHP at $P=1.2 \cdot 10^{9} \mathrm{~Pa}$, larger clusters of nickel atoms with lenticular and spherical shapes decay. It should be noted that in this case, apart from the usual decay, the decomposition of layers of some impurity clusters, which have a multilayer structure, is also observed. In turn, the observed irreversible character of the dependence of the resistivity on pressure, at values of $P>4 \cdot 10^{8} \mathrm{~Pa}$, also confirms that under the influence of ARHP there is a decay of accumulations of impurity nickel atoms.

Comprehensive structural analyzes of the states of impurity clusters before and after exposure to ARHP in $n$-Si $<\mathrm{Co}>$ samples also indicate that impurity clusters decompose under the influence of pressure. Comparative analyzes of $n$-Si $<\mathrm{Co}>$ samples before and after ARHP at $P=4 \cdot 10^{8} \mathrm{~Pa}$ showed that the number of impurity clusters of cobalt atoms existing in the sample volume, having needle-like and disc-like shapes with sizes up to $0.5 \mu \mathrm{m}$, sharply decreases. Under the influence of ARHP at $P=8 \cdot 10^{8} \mathrm{~Pa}$, the decomposition of relatively large accumulations of cobalt $(d>0.5 \mu \mathrm{m})$ with lenticular and spherical shapes that have a multilayer structure is observed.

\section{CONCLUSIONS}

Thus, based on the experimental results obtained, it is assumed that the decrease in the value of the resistivity of silicon samples with impurity accumulations of nickel and cobalt, at the early stages of exposure to ARHP, is due to an increase in the concentration of electroactive impurity atoms due to the shift of energy levels, which occurs as a consequence of the deformation of the crystal structure of silicon.
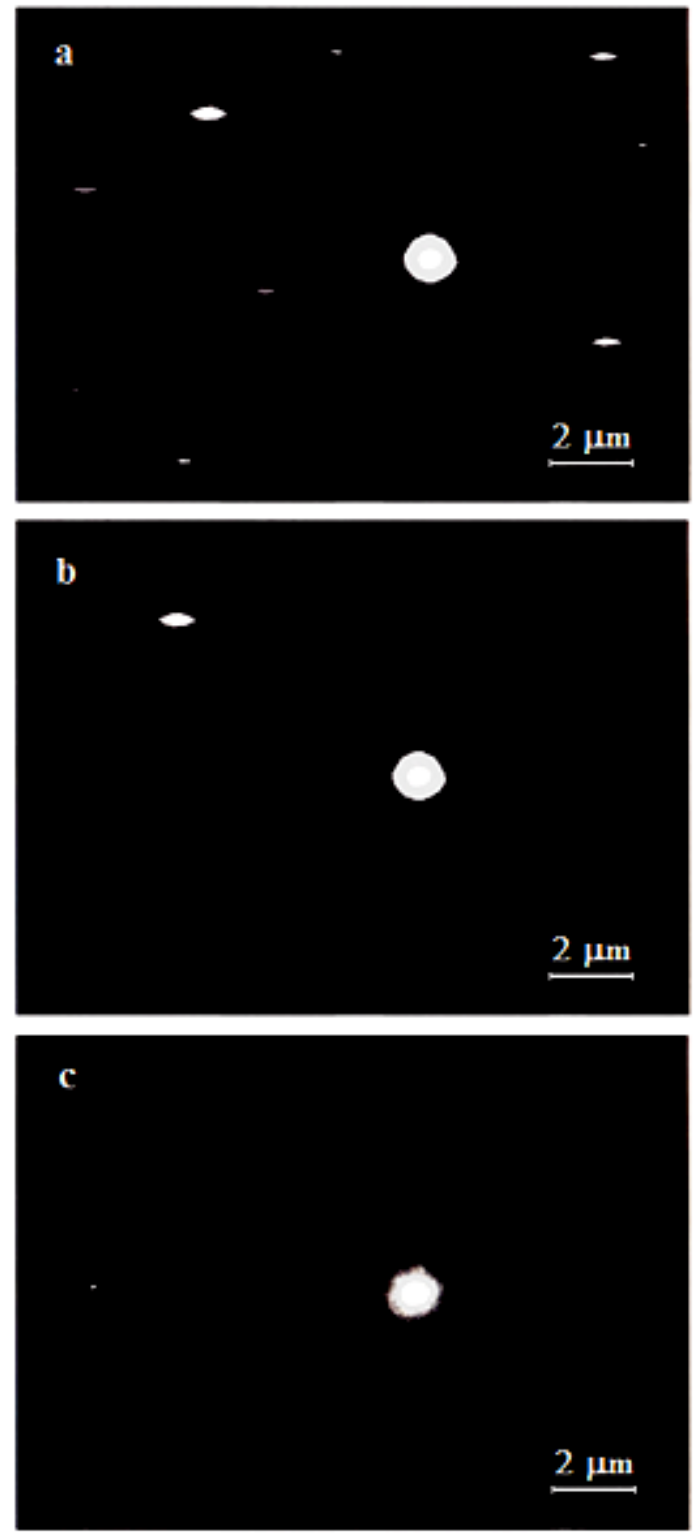

Fig. 4 - Influence of ARHP on impurity accumulations of nickel in silicon: $\mathrm{a}-$ before exposure to ARHP, $\mathrm{b}-P=6 \cdot 10^{8} \mathrm{~Pa}$, and c $-P=1.2 \cdot 10^{9} \mathrm{~Pa}$

It was found that under the influence of ARHP at $P=6 \cdot 10^{8} \mathrm{~Pa}$, small (up to $1 \mu \mathrm{m}$ ) impurity accumulations of nickel with needle-like and disc-like shapes decay, which leads to a sharp increase in the value of $\rho$ for $n$-Si $<\mathrm{Ni}>$ samples up to $\sim 8$ times. The impact of ARHP at $P=1.210^{9} \mathrm{~Pa}$ on these samples leads to the decomposition of larger clusters of nickel atoms with lenticular and spherical shapes. As a result of this, the value of the resistivity of the samples again sharply increases and the relative growth reaches 10 times.

It was revealed that the observed increase in the value of the resistivity of $n$-Si $<\mathrm{Co}>$ samples up to 7 times under the influence of ARHP at $P=4 \cdot 10^{8} \mathrm{~Pa}$ occurs due to the decay of clusters of impurity cobalt atoms. It was found that the decay sequence of impurity clusters depends on their size and shape. Initially, clusters with needle-shaped and disc-shaped forms, the sizes of which reach up to 0.5 microns, are subject to decay. Further, under the influence of ARHP at 
$P=8 \cdot 10^{8} \mathrm{~Pa}$, an increase in the resistivity value is observed up to $\sim 13$ times, which occurs due to the decay of larger clusters of cobalt atoms $(d>0.5 \mu \mathrm{m})$.

\section{ACKNOWLEDGEMENTS}

The authors express their sincere gratitude to the staff of the Institute of Geology and Geophysics of the
Academy of Sciences of the Republic of Uzbekistan for their support in carrying out some experimental studies. They also express their gratitude to the Doctor of Physical and Mathematical Sciences, academician Zainabidinov S.Z. for participation in the discussion of the obtained results.

\section{REFERENCES}

1. X. Li, L.B. Yang, W.H. Ping, H.X. Dong, Y Sun, Appl. Mech. Mater. 55-57, 348 (2011).

2. E.B. Asgerov, N.T. Dang, D.I. Ismayilov, S.E. Kichanov, R.N. Mehdiyeva, A.I. Madadzada, S.H. Jabarov, E.M. Kerimova, E.V. Lukin, Mod. Phys. Lett. B. 29 No 8, 1550024 (2015).

3. A.M. Musaev, Semiconductors 52, 31 (2018).

4. Thao P. Nguyen, Ji Hoon Shim, Phys. Chem. Chem. Phys. 18, 13888 (2016).

5. E. Weber, H.G. Riotte, J. Appl. Phys. 51, 1484 (1980).

6. Ch. Sun, H.T. Nguyen, F.E. Rougieux, D. Macdonald, J. Cryst. Growth 460, 98 (2017).
7. A. Haarahiltunen, M. Yli-Koski, H. Savin, Energy Procedia No 8, 355 (2011).

8. N.A. Turgunov, Inorganic Mater. 54 No 12, 1183 (2018).

9. N.A. Turgunov, E.Kh. Berkinov, D.Kh. Mamazhonova, Appl. Phys. No 3, 40 (2020).

10. V.I. Fistul, A.R. Turaev, S.Z. Zainabidinov, phys. stat. soll. (a) 136, 337 (1993).

11. S.Z. Zainabidinov, P.I. Baranskiy, I.N. Karimov, A.R. Turaev, Kh.Kh. Karimberdiev, Solid State Electron. 38, 693 (1995).

12. O.V. Feklisova, E.B. Yakimov, Phys. Solid Sate 53 No 6 , 1175 (2011).

\title{
Розпад домішкових кластерів атомів нікелю та кобальту в кремнії під впливом тиску
}

\author{
N.A. Turgunov, E.Kh. Berkinov, D.Kh. Mamajonova \\ Research Institute of Physics of Semiconductors and Microelectronics at the National University of Uzbekistan, \\ 20, Yangi Almazar St., 100057 Tashkent, Republic of Uzbekistan
}

\begin{abstract}
Досліджено вплив всебічного гідростатичного тиску (ARHP) на електрофізичні властивості монокристалів кремнію, легованих нікелем та кобальтом. Після високотемпературного дифузійного легування в об'емі зразків $n$ - $\mathrm{Si}<\mathrm{Ni}>$ та $n$ - $\mathrm{Si}<\mathrm{Co}>$ виявлено скупчення домішкових атомів нікелю та кобальту. Методом електронно-зондового мікроаналізу отримано мікрофотографії скупчень домішок та визначено їх структурні форми. Залежно від розміру та форми ці домішкові кластери мають одношарову або багатошарову структуру. Під впливом ARHP значних змін у питомому опорі вихідних зразків не спостерігається. На відміну від них, у зразках кремнію, легованих нікелем або кобальтом, під впливом тиску питомий опір значно зростає. Виявлено, що під впливом ARHP в діапазоні $P=10^{8}$ $1.6 \cdot 10^{9}$ Па домішкові скупчення нікелю та кобальту в кремнії розкладаються, що призводить до збільшення питомого опору зразків у кілька разів. Порівняльний аналіз морфологічних параметрів скупчень домішок до та після впливу ARHP показав, що процес розпаду цих кластерів відбувається у певній послідовності та залежить від їх розміру та форми. У зразках $n$ - $\mathrm{Si}<\mathrm{Ni}>$ спочатку під впливом ARHP при $P=6 \cdot 10^{8}$ Па спостерігався розпад домішкових кластерів розміром до 1 мкм, які мали голкоподібну та дископодібну форми. А в зразках $n$ - $\mathrm{Si}<\mathrm{Co}>$ під впливом ARHP при $P=4 \cdot 10^{8}$ Па спостерігався розпад голкоподібних та дископодібних домішкових кластерів розміром до 0,5 мкм. При більш високих значеннях ARHP ( $P \geq 8 \cdot 10^{8}$ Па) було виявлено розкладання домішкових скупчень нікелю та кобальту з відносно великими розмірами, які мають лінзоподібну та сферичну форму.
\end{abstract}

Ключові слова: Тиск, Кремній, Нікель, Кобальт, Питомий опір, Розпад кластерів. 